\title{
Theological Librarianship: Toward a Profile of a Profession
}

\section{Rashelle S. Karp and Andrew J. Keck}

Theology touches almost everyone at one time or another. The librarians who maintain, preserve, and disseminate theological information are critical to the perpetuation of theological study and enlightenment. However, the literature of librarianship is strangely silent on the topic of theological librarianship, and especially on issues that are unique to theological librarians - those who work with theologically or religiously focused collections or libraries that support the education and training of people preparing for the ministry.

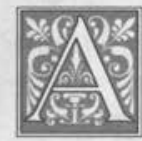

search of Library Literature (1984-1994) yields fewer than forty citations on the topic of theological libraries or librarians; a major review of the literature written between 1924 and 1984 on the topic cites only another twenty-five articles. ${ }^{1}$ Selected studies that are considered landmarks include a 1934 study of ministerial education; a 1957 study of theological education; a 1970 demographic survey of members of the American Theological Library Association (ATLA); surveys in 1971 and 1980 regarding faculty status among theological librarians; and a 1984 survey concerning unique problems facing theological librarians of the $1990 \mathrm{~s}^{2-7}$

The literature on theological librarianship notes: (1) the need for theological librarians to acquire library, theological library, and theological professional education; (2) a paradox that theological librarians must formulate collection development policies that are not denominational but collections that are; (3) the criti- cal role of theological librarians as preservationists and developers of special cataloging and classification schemes that provide differentiation among specialized and diverse denominational resources; and (4) definitions of theological librarians as people performing ministry and as people who provide linkages among theology, church, scholarship, education, diverse constituencies, and both scholarly and popular literature..$^{8-24}$

\section{Methodology}

Based on the literature, researchers developed a questionnaire and mailed it to the 371 American members of the ATLA listed in the ATLA Membership Directory of 1994. (Survey questionnaires are available from the authors.) Researchers received a total of 243 usable responses, yielding a response rate of 65.4 percent. They then used the SAS statistical package to manipulate coded data, and data from open-ended questions were transcribed verbatim and then analyzed to

Rashelle S. Karp is a Professor of Library Science, Department of Library Science, Clarion University of Pennsylvania. Andrew J. Keck is Acquisitions Assistant at the Clifford E. Barbour Library of the Pittsburgh Theological Seminary, an MSLS student at Clarion University of Pennsylvania, and a part-time local pastor. 
discern trends and patterns. Additionally, researchers matched each library represented by a respondent to its entry in the American Library Directory (online, Apr. 1995 ) in order to determine the proportionate representation among types of libraries (religious, college and university religious, special religious, or public).

\section{Results}

\section{Demographics}

Libraries represented. Respondents represented 137 religious libraries, 36 college and university (religious) libraries, $25 \mathrm{col}$ lege and university libraries, 24 special (religious) libraries, and 3 public libraries. ${ }^{25} \mathrm{~A}$ little over 7 percent of the represented libraries could not be categorized.

Personal characteristics of respondents. The average age of respondents was forty-eight years, and the sample comprised 56.8 percent males and 43.2 percent females. A little over 14 percent of the respondents filled the post of clergy at a local congregation, and out of this group, a little under half ( $44.8 \%$ ) received payment for their clergy work. Additionally, 34.6 percent of all the respondents indicated that they were ordained. The denominations to which respondents belonged covered a broad range of Christian sects, with the most represented denominations including Roman Catholic, Presbyterian (USA), and Episcopal (see table 1). A respondent on average had worked 13.5 years as a theological librarian.

As for respondents' personal theological positions, 39.4 percent indicated a liberal position, 27.1 percent indicated a moderate position, and 33.5 percent indicated a conservative position. In modest contrast, when asked to rate the theological positions of their parent institutions, 29.2 percent of the respondents indicated a liberal position, 25.4 percent indicated a moderate position, and 40.2 percent indicated a conservative position; 5.1 percent indicated that their institutions had no theological position.

In terms of involvement in the activities of their local congregations, 11.3 percent of the respondents indicated that they were not involved in the religious activities of their local congregations, and 23.6 percent indicated that they were not involved in the social activities of their local congregations. A little over 65 percent indicated moderate levels of involvement in the religious activities of their local congregations, and 66.7 percent indicated moderate levels of involvement in the social activities of their local congregations. Finally, 23.4 percent indicated that they were 
very involved in the religious activities of their local congregations, and 9.7 percent indicated that they were very involved in the social activities of their local congregations. Respondents had mostly positive feelings about their local congregations $(79.7 \%)$ and the denominations to which they personally belonged (68.7\%).

Employing libraries' characteristics. In terms of staffing, the average number of full-time paid library staff at institutions of responding librarians was seven; the average number of parttime paid library staff was six; and the average number of full or parttime library volunteers was one. The majority of the libraries employed between one and eight full-time paid staff, between zero and six part-time paid staff, and no volunteers. Respondents indicated, on average, that their current levels of staffing were moderately adequate. Similarly, on average, respondents indicated that their current levels of funding were moderately adequate.

When asked what three positions they would most like to add to their library, respondents indicated that their top priorities included reference, cataloging, and automation professionals (see table 2). Degrees considered to be the most important credentials for those filling these positions included a master of library science (MLS), a bachelor's degree, and a theology degree (see table 3 ). Finally, respondents indicated that the areas which were most in need of funding at their libraries included books and journals, elec-
TABLE 2

Recommended Augmentations of Library Staff $(n=588)$

No. \%

Public Service/Reference Professional

$92 \quad 15.6$

$\begin{array}{ll}65 & 11.0\end{array}$

$54 \quad 9.1$

$52 \quad 8.8$

47
46

$46 \quad 7.8$

$41 \quad 6.9$

$26 \quad 4.4$

$25 \quad 4.2$

$20 \quad 3.4$

213.5

$21 \quad 3.5$

$17 \quad 2.8$

$13 \quad 2.2$

$9 \quad 1.5$

$9 \quad 1.5$

$9 \quad 1.5$

61.0

$5<1$

$5<1$

$3<1$

Paraprofessional for Research Support $1<1$

Generalist/Floating Professional $\quad 1<1$

tronic resources, and automation of library processes (see table 4).

Academic status of librarians. Faculty status only was held by 23.1 percent of the respondents, 26 percent had administrative status only, 25.6 percent held a combination of both faculty and administrative status, and 25.2 percent held a rank other than administrative or faculty status. The types of rank identified by those who held other than administrative or faculty status included paraprofessional or staff, academic, or professional (but not eligible for tenure); faculty (but not eligible for tenure, sabbaticals, or faculty vacation schedules), adjunct faculty (without voting privileges), faculty (but without rank or tenure); faculty (but for the calendar year with salary adjustments); parish-based rank; permanent staff; professional/technical staff; librar- 


\begin{tabular}{|c|c|c|}
\hline \multicolumn{3}{|c|}{$\begin{array}{c}\text { TABLE 3 } \\
\text { Recommended Degrees for Library Staff } \\
\text { Augmentation }(\mathrm{n}=\mathbf{5 4 9})\end{array}$} \\
\hline Recommended Degrees & Number & $\%$ \\
\hline Master's of Library Science & 248 & 45.1 \\
\hline Bachelor's Degree & 109 & 19.8 \\
\hline $\begin{array}{r}\text { Theology Degree - Master's } \\
\text { Bachelor's }\end{array}$ & $\begin{array}{l}51(7.0 \%) \\
19(2.6 \%)\end{array}$ & 12.7 \\
\hline Master's of Divinity & 42 & 7.6 \\
\hline Bachelor's of Science in & & \\
\hline Information Science & 29 & 5.2 \\
\hline High School Diploma & 19 & 3.4 \\
\hline Second Master's (history, music) & 15 & 2.7 \\
\hline Doctorate & 8 & 1.4 \\
\hline Master's of Religion & 3 & $<1$ \\
\hline Master of Theological Studies & 3 & $<1$ \\
\hline Conservation Degree & 3 & $<1$ \\
\hline
\end{tabular}

salaries were lower than the salaries of administrators at their institutions.

Degrees held by library staff. The average number of library staff per library holding an MLS degree only was two; the average number of library staff per library holding only a theological degree was one. In addition, the average number of library staff per library holding both an MLS degree and a theological degree was one. In terms of sheer numbers, the most represented postbaccalaur-eate degree was the MLS, followed by

ian status; middle management; and managerial/professional librarian status.

Salaries. Over half of the respondents $(53.1 \%)$ reported salaries between $\$ 22,501$ and $\$ 37,500$ per year. ${ }^{26}$ None of the respondents perceived their salaries to be outrageously higher than they should be, but 7.5 percent did perceive them to be more than reasonable, and 52.2 percent rated their salaries as reasonable. A little over 35 percent believed them to be lower than they should be, and 4.2 percent believed their salaries to be outrageously lower than they should be. The majority of respondents indicated that their salaries were reasonable or slightly lower than reasonable.

Over half $(70.4 \%)$ of the respondents indicated that, theoretically, theological schools should provide a mix of professional education and academic education....

In comparing their salaries with faculty at their institutions, respondents indicated, on average, that their salaries were slightly higher. In contrast, the majority of respondents indicated that their an MLS plus a theological degree, and, lastly, theological degrees only.

Professional degrees most often held by the respondents included: a MLS (88\%), master of divinity (39\%), doctor of philosophy (17\%), master of arts in religion (16\%), master of theological studies (9\%), master of the science of theology $(6 \%)$, and doctor of ministry (1.6\%). Other degrees noted by 23 percent of the respondents included the certificate in archives administration, master of arts, master of business administration, master of church music, master of theology, bachelor of sacred theology, sacred theologiae lector or licentiatus, master of arts in Christian religion, master of theology, master of religious education, master of science, master of education, master of philosophy, doctor of canon law, master of sacred music, master of religious education in missions, licentiate in philosophy, doctor of the science of theology, master of Christian spirituality, certificate of advanced studies in library science, and the MLS. Analysis of the universities at which respondents obtained their degrees indicated tremendous variety; no single university emerged as more representative than any other. 


\section{Attitudes of Respondents Regarding Their Parent Institutions, Theological Librarianship, and Ministry}

Attitudes toward parent institutions. The majority of the respondents $(89.9 \%)$ indicated that they held neutral or positive feelings about their parent institutions, and overwhelmingly indicated the following reasons for their responses:

- commitment and support by faculty and administration for the goals of highquality education and library service;

- congruence between respondents' personal philosophies and their institutions' missions related to ministry, theological education, and spiritual ethos; and

- collegiality among faculty.

Other reasons frequently cited included quality and enthusiasm of students and faculty, visionary leadership, diversity within the institution, humane treatment of employees, and the librarians' ability to affect institutional decision making. Respondents who held mostly negative feelings about their parent institutions $(10.1 \%)$ indicated difficulties keeping up with librarianship, theology, and technology; sexism; disadvantages of those without clergy degrees; poor leadership; lack of support for the library; and lack of congruence between respondents' personal philosophies and their institutions' missions and goals related to theology and denominational focus.

Beliefs about the purpose of a theological school. Over half $(70.4 \%)$ of the respondents indicated that, theoretically, theological schools should provide a mix of professional education and academic education; 21.3 percent believed that theological schools should focus on pro- fessional; and 8.3 percent indicated that theological schools should focus on academic education. When asked about the main purpose of the theological school supported by their library, 50 percent indicated that their institution provided a mixture of academic and professional education; 12.9 percent indicated a focus on academic education; and 37.1 percent indicated a focus on professional education.

Perceptions about the positives and negatives of theological librarianship. Respondents overwhelmingly indicated the following positive attributes of working as theological librarians (summarized by authors):

- the theological and spiritual focus of their work and the environment in which they worked;

\begin{tabular}{|c|c|c|}
\hline \multicolumn{3}{|c|}{$\begin{array}{c}\text { TABLE 4 } \\
\begin{array}{c}\text { Recommended Areas for Library Funding } \\
\text { Augmentation }(\mathrm{n}=561)\end{array}\end{array}$} \\
\hline Recommended Areas & No. & $\%$ \\
\hline Books/Journals & 151 & 26.9 \\
\hline Electronic Resources & 120 & 21.3 \\
\hline Automation of Library Processes & 110 & 19.6 \\
\hline Technical Services/Processing & 33 & 5.8 \\
\hline $\begin{array}{l}\text { Facilities (shelving, building } \\
\text { expansion off-site storage) }\end{array}$ & 32 & 5.7 \\
\hline $\begin{array}{l}\text { Equipment (fax, PC/CD-ROM } \\
\text { workstations, microform readers, } \\
\text { equipment upgrades and } \\
\text { replacements, furniture) }\end{array}$ & 28 & 4.9 \\
\hline Preservation/Conservation & 24 & 4.2 \\
\hline Special Collections & 19 & 3.3 \\
\hline Retrospective Conversion Cataloging & 11 & 1.9 \\
\hline Salaries & 7 & 1.2 \\
\hline Professional Growth/Travel & 6 & 1.0 \\
\hline Microforms & 6 & 1.0 \\
\hline Audiovisual Materials & 5 & $<1$ \\
\hline Document Delivery/ILL Postage & 2 & $<1$ \\
\hline Binding & 2 & $<1$ \\
\hline Security System & 2 & $<1$ \\
\hline Instructional Services & 1 & $<1$ \\
\hline Supplies & 1 & $<1$ \\
\hline Endowments & 1 & $<1$ \\
\hline
\end{tabular}


- the perception that they were performing ministry work;

- the work of being a librarian;

- being part of a seminary community;

- the humanizing effect of their institutions' theological focuses.

The most frequently cited negative attributes of working as a theological librarian included (summarized by authors):

- difficulties keeping up with theology, librarianship, and technology;

- lack of financial support for the library;

- poor administration of seminaries;

- low salaries;

- too much paperwork;

- lack of status, recognition, and respect;

- working in a sexist, male-dominated environment; and

- denominational and seminary politics.

Attitudes toward the importance of dealing pastorally with people. When asked about the relative importance of dealing with people in a pastoral way, 24 percent of the respondents indicated that it was not important for a theological librarian to deal pastorally with people, 23.5 percent believed it was moderately important, and 52.5 percent indicated that this type of behavior was very important. When asked whether they, themselves, dealt with patrons and colleagues in a pastoral way, 29.4 percent responded that they did not, 23.0 percent indicated that they behaved pastorally to a moderate degree; and 47.7 percent indicated that they behaved pastorally to a great degree.

Perceptions of theological librarianship as a ministry. When asked whether they perceived their work as theological librarians as a form of ministry, 9.8 percent of the respondents indicated that they believed their work to be a form of ministry, and 26.7 percent held a professional image of themselves as more a person involved in ministry than an infor- mation professional. In contrast, 10.2 percent of the respondents indicated that they did not perceive their work as a form of ministry and 36.2 percent held a professional image of themselves as more an information professional than a person involved in ministry. Just over 37 percent of the respondents held a professional image of themselves that included both roles equally.

\section{Perceptions of theological librarian-} ship as a calling. When asked about whether theological librarianship was a vocational "calling," 67.8 percent of the respondents reported that theological librarianship represented a vocational calling for them, and 32.2 percent indicated that it did not. Almost all of the respondents who indicated that theological librarianship was a vocational calling indicated that their choice to be librarians was secondary to their choice to be involved in the work of ministry; librarianship represented the vehicle through which they could pursue a higher calling.

Comparisons with other types of special librarians. It is illuminating to draw comparisons between theological librarianship and other niches in the profession, such as law and medical librarianship. Like theological librarians, law and medical librarians often possess a master's degree in addition to the MLS. ${ }^{27-29}$ Additionally, law, medical, and theological librarians deal with unique ethical issues. For example, job satisfaction for theological librarians seems to be linked to the degree of agreement between institutional and personal theological/ethical belief systems. Medical and law librarians must deal with ethical issues related to the nature of the information with which they work and the dilemma that, although the library code of ethics promotes open access to all information, irresponsible dissemination of medical and legal information can harm more than help. Thus, for medical and law librarians, professional ethics also come into conflict with personal beliefs..$^{30-32}$ 
Finally, like theological librarians, law and medical librarians display a tendency to view their work as a calling rather than a profession, believing that through providing crucial information, they are aiding patients and clients as much as the physicians and lawyers themselves. This type of attitudinal environment may contribute to special librarians' beliefs that they "make a difference." 33 And perhaps because of these feelings, job satisfaction is high among law, medical, and theological librarians. However, researchers note that burnout often occurs when reality consistently falls short of the ideals the librarian wishes to believe. ${ }^{34}$

\section{Conclusions and Suggestions for Further Research}

The present research indicates that Christian theological librarians working in religious or college or university religious libraries: (1) are professionally and spiritually fulfilled; (2) hold theological belief systems that mirror those of their parent institutions; (3) believe their work to be a form of ministry; and (4) identify theological librarianship as a calling. The research also indicates that the theological and spiritual focus of theological librarians' work is an integrated and important component of their attitudes toward theological librarianship. However, many questions still remain from the research.

It would be helpful to explore more fully respondents' comments regarding the positives and negatives of theological librarianship. For example, how prevalent are these perceptions, and how do they contribute to the professional image of theological librarians? In addi-

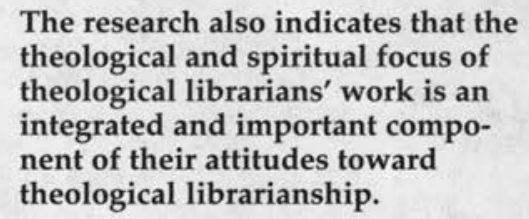

tion, must a theological librarian have a theological degree in order to meet the needs of her or his patrons adequately?

Other interesting potential areas to investigate are the role of nonlibrarians/ paraprofessionals within theological libraries, or the extent to which theological librarians' professional images reflect those of librarians working in other types of special libraries. Finally, the present research provides information about how Christian theological librarians view their work. However, more information is needed about the ways in which nonChristian theological librarians view the profession of theological librarianship. ${ }^{35}$

\section{Notes}

1. Ron Jordahl, "The Interdisciplinary Nature of Theological Librarianship in the United States," Libraries \& Culture 25 (spring 1990): 153-70.

2. The Education of American Ministers, ed. Mark A. May (New York: Institute of Social and Religious Research, 1934).

3. H. Richard Niebuhr, Daniel Day Williams, and James M. Gustafson, Advancement of Theological Education (New York: Harper \& Brothers, 1957).

4. David William Faupel, "Reference Service Provided by ATLA Librarians," ATLA Newsletter 19 (Aug. 14, 1971): 19-26.

5. G. Paul Hamm, "The Library Role in 1971: A Survey of Administrators and Librarians of AATS," ATLA Newsletter 21 (Aug.18, 1973): $28-47$. 208.

6. James C. Pakula, Faculty Status and Theological Librarians, ERIC Document Number 200

7. Stephen L. Peterson, "Theological Librarians for the Twenty-First Century: Project 2000 Final Report," Theological Education 20 (supp: no. 3); entire issue.

8. Doralyn Hickey, "Education for Theological Librarianship: A Library School Perspective," ATLA Newsletter 11 (Feb. 15, 1964): 45-51. 
9. Robert F. Beach, "Education for Theological Librarianship," in American Theological Library Association. Summary of Proceedings. Tenth Annual Conference (Evanston, Ill.:, ATLA, 1956): 9-13.

10. Raymond P. Morris, "The Libraries of Theological Seminaries," in The Education of American Ministers, ed. Mark A. May (New York: Institute of Social and Religious Education, 1934): 149-91.

11. "The Vocation of the Theological Librarian," American Theological Library Association. Summary of Proceedings. 17th Annual Conference (Evanston, Ill.: ALTA, 1963): 114-22.

12. Connolly C. Gamble, "Contemporary Challenges to Theological Librarianship," American Theological Library Association. Summary of Proceedings, 16th Annual Conference (Evanston, Ill.: ATLA, 1962): 44-48.

13. Joseph P. Brown, "Current Concerns: College/University, Seminary Libraries," Catholic Library World 54 (Oct. 1982): 101-2.

14. James Dunkly, "Some Values in Theological Librarianship," American Theological Library Association. Summary of Proceedings. 46th Annual Conference (Evanston, Ill.: ATLA, 1992): 194.

15. Earle Hilgert and Elvire Hilgert, "The Librarian-Educator in a Theological School," in Essays on Theological Librarianship, ed. Peter De Klerk and Earle Hilgert (Philadelphia: ATLA, 1980): $119-42$.

16. Peterson, "Theological Librarians for the Twenty-First Century," 25.

17. Niels Sonne, "Current Trends in Theological Libraries," Library Trends 9 (Oct. 1960): entire issue.

18. Joseph P. Brown, "Current Concerns: College/University, Seminary Libraries," Catholic Library World 54 (Nov. 1982): 146.

19. Molly Lyons, "The Seminary Library," Catholic Library World 58 (July/Aug. 1986): 46.

20. Stephen L. Peterson, "The More Things Change-The More Things Change: Theological Libraries in the 1990s," Theological Education (spring 1990): 148-49.

21. James Dunkly, "Theological Libraries and Theological Librarians in Theological Education," American Theological Library Association. Summary of Proceedings, 45th Annual Conference (Evanston, Ill.: ATLA, 1991): 231.

22. Rosalyn Lewis, "Theological Librarianship: Service, Not Servitude," American Theological Library Association. Summary of Proceedings, 42nd Annual Conference (Evanston, Ill.: ATLA, 1988): 154-57.

23. James J. Kortendick, "The Theological Librarian - His Commitment and Strategy," American Theological Library Association. Summary of Proceedings, 19th Annual Conference (Evanston, Ill.: ATLA, 1965): 105-11.

24. John Frederick Harvey, "Scholarly and Popular Religious Libraries," International Library Review 19 (Oct. 1987): 359-86.

25. Categories are based on identifications in the American Library Directory.

26. It should be noted that the questionnaire did not specifically ask for "cash salary" as opposed to "cash value" of salary. Therefore, some reported salaries may be higher, especially for respondents who also receive housing and food as part of their total compensation package.

27. B. B. Bonney, "The Controversy Over Dual Degrees for Law Librarians," Legal Reference Services Quarterly 11(1/2) (1991): 127-33.

28. Rachael K. Goldstein Anderson, "Reinventing the Medical Librarian," Bulletin of the Medical Library Association 77 (Oct. 1989): 323-31.

29. Kathleen M. Carrick, "Silk v Corduroy: The Status of Men and Women in Law Librarianship," Law Library Journal 78 (summer 1986): 425-41.

30. Ibid.

31. Jitka M. Hurych and Ann C. Glenn, "Ethics in Health Science Librarianship," Bulletin of the Medical Library Association 75 (Oct. 1987): 342-48.

32. Guiliano Chicco, "Ethics and Law Librarianship: A Panel Discussion," Law Library Journal 83 (winter 1991): 1-19.

33. Ruth Holst, "Hospital Libraries in Perspective," Bulletin of the Medical Library Association 79 (Jan. 1991): 1-9.

34. Veneese C. Nelson, "Burnout: A Reality for Law Librarians?" Law Library Journal 79 (spring 1987): $267-75$.

35. Laura Berner Cohen, "Synagogue Libraries: Making It on Their Own," Special Libraries 86 (spring 1995): 91-106. 


\section{INFORMATION COMES IN ALL SHAPES AND SIZES}

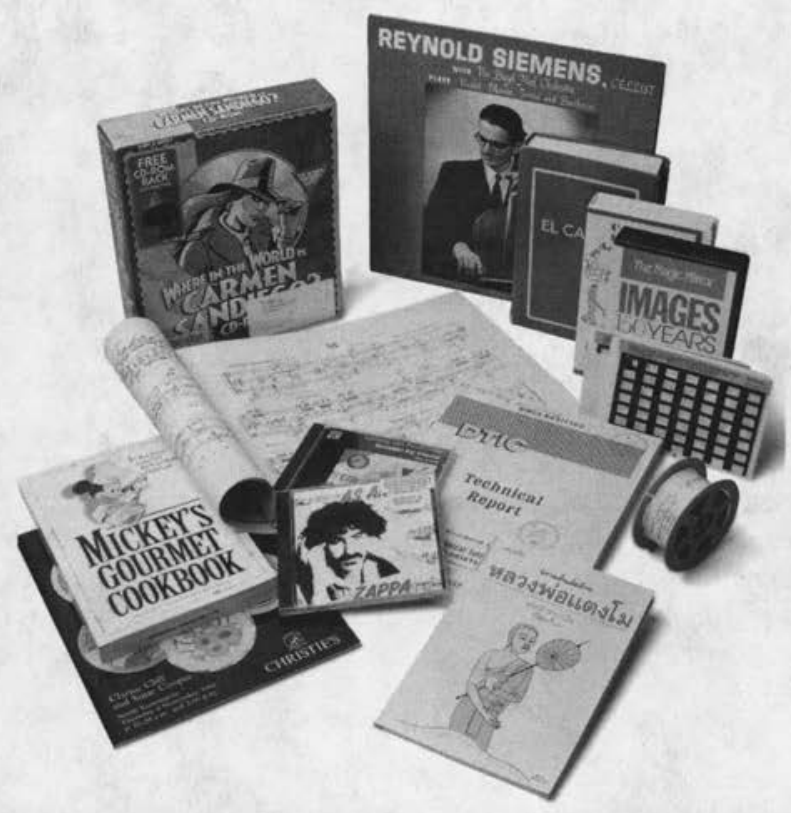

\section{OCLC's TECHPRO Service catalogs it all}

With library resources so stretched, it's challenging to keep your cataloging upto-date. And it's frustrating, because uncataloged materials are inaccessible to your patrons.

OCLC's TECHPRO Service can help. Since 1985, we've offered solutions for libraries that have cataloging backlogs or need ongoing cataloging support.

- Customized cataloging and physical processing to match your specifications

- Cataloging for all bibliographic formats and many languages

- Quality cataloging at prices that can reduce your overall cataloging costs

Contract cataloging for books, serials, scores, non-print items, foreign language materials and more-it's cataloging in all shapes and sizes-from OCLC's TECHPRO Service.

1-800-848-5878, ext. 4386

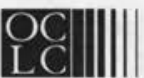

